\title{
RESPIRATORY INSUFFICIENCY AND ITS TREATMENT FOLLOWING PAEDIATRIC CARDIOVASCULAR SURGERY*
}

\author{
K. BROWN, M.D., † A. E. JoHNSTON, M.D., C.M., F.R.C.P.(C), AND \\ A. W. CONN, M.D., B.SC.(MED.), F.R.C.P.(C)
}

The Scandinavian Poliomyeirtis EPIDEMic of the early 1950's resulted in great advances in the management of respiratory insufficiency. The improved methods which evolved have been more recently applied to the postoperative cardiovascular patient. ${ }^{1}$ These, in conjunction with advances in surgical technique and a better understanding of the metabolic derangements that occur, have contributed to a reduction of postoperative morbidity and mortality.

\section{ReSPIRATORY INSUFFICIENCY}

Respiratory insufficiency develops whenever the respiratory mechanism is unable to provide adequate arterial oxygenation or elimination of carbon dioxide. An arterial oxygen tension $\left(\mathrm{P}_{\mathrm{O}_{2}}\right)$ below $60 \mathrm{~mm}$. $\mathrm{Hg}$ and a carbon dioxide tension $\left(\mathrm{P}_{\mathrm{CO}_{2}}\right)$ above $49 \mathrm{~mm}$. $\mathrm{Hg}$ indicate respiratory insufficiency. ${ }^{2,3}$ Because of the characteristics of the oxyhaemoglobin dissociation curve, arterial oxygen tension is the more exact indication of oxygen deficiency. The oxygen saturation may be in the range of 70 to 80 per cent when the arterial $P_{\mathbf{O}_{2}}$ has fallen to the range of 40 to $50 \mathrm{~mm}$. $\mathrm{Hg}$. Therefore, cyanosis does not become apparent until ventilation is grossly reduced.

An increase in the inspired oxygen concentration will usually improve oxygenation, whereas carbon dioxide elimination is entirely dependant upon gaseous exchange volume. Thus, all patients with hypoventilation will retain carbon dioxide. ${ }^{4}$

Hypoxaemia is present in all types of respiratory failure. When hypercapnia is also present it may be due to (a) inadequate ventilation resulting from lack of neural drive or muscular weakness, or as a result of poor pulmonary or thoracic function; (b) ventilation-perfusion imbalance which may occur when the perfusion of the ventilated lung is diminished.

Hypoxaemia may also occur without hypercapnia because carbon dioxide diffuses more rapidly than oxygen. This may take place (a) when the alveolar capillary membrane is damaged or when the pulmonary capillary bed is inadequate; (b) as a result of ventilation-perfusion imbalance when there is reduced ventilation of perfused lung. ${ }^{8}$

In the absence of respiratory insufficiency, hypoxaemia may be the result of right to left cardiac shunt.

- From the Department of Anaesthesia, The Hospital For Sick Children, Toronto.

fCurrently Registrar, Department of Anaesthesia, Royal Melbourne Hospital, Australia. 


\section{Aetiology}

The clinical conditions which may cause respiratory insufficiency can be conveniently grouped on an anatomical basis. Those following cardiovascular surgery are classified in Table I. During the immediate postoperative period the patient's ability to maintain adequate ventilation may be diminished by several of these conditions.

TABLE I

Respiratory Insufficiency Following Cardiovascular Surgery

\begin{tabular}{|c|c|}
\hline Respiratory centre & $\begin{array}{l}\text { Central depressant drugs } \\
\text { Embolism (air, thrombus) }\end{array}$ \\
\hline Neuromuscular & Muscle relaxants. \\
\hline Thoracic cage & $\begin{array}{l}\text { Severe potassium imbalance } \\
\text { Incisional pain }\end{array}$ \\
\hline & Limitation of diaphragmatic excursion \\
\hline Airway & $\begin{array}{c}\text { Obstruction一 secretions } \\
\text { —blood }\end{array}$ \\
\hline Pulmonary paremchyma & $\begin{array}{l}\text { a. Atelectasis - airway obstruction } \\
\text {-external compression of lung } \\
\text {-denitrogenation }\left(100 \% \mathrm{O}_{2}\right) \\
\text {-reduced surfactant } \\
\text { b. Consolidation-pneumonia } \\
\text { c. Pulmonary vascular disease-pulmonary hypertension } \\
\text {-chronic elevation left atrial pressure } \\
\text { - acute and subacute pulmonary } \\
\text { oedema } \\
\text {-interstitial haemorrhage } \\
\text {-intimal deposition }\end{array}$ \\
\hline Pleura & $\begin{array}{l}\text { d. Pre-existing pulmonary disease } \\
\text { a. Haemothorax } \\
\text { b. Pneumothorax } \\
\text { c. Chylothorax }\end{array}$ \\
\hline
\end{tabular}

Respiratory centre. Central respiratory depression may be due to the residual effects of anaesthetic agents, or the drugs used for pain relief and sedation postoperatively. Rarely cerebral emboli (air or thrombus) may contribute to central depression.

Neuromuscular. Muscle weakness may result from incomplete reversal of muscle relaxants, from the effects of severe potassium imbalance, or from preexisting neuromuscular diseases.

Thoracic cage. Incisional pain may cause a reduction in tidal volume, breath holding, and a decreased ability to cough. Analgesic drugs are the usual form of treatment, although Bromage ${ }^{5}$ has demonstrated the advantages of high epidural anaesthesia in adults, while others have advocated the use of a low concentration of nitrous oxide. Controlled and assisted ventilation reduces post-thoracotomy pain-probably by reducing the respiratory effort necessary. Because the diaphragm is the only effective muscle of respiration during the early months of life any limitation of diaphragmatic movement impairs ventilation. Of common occurrence is a stomach distended with air, ileus, or a rapidly enlarging liver.

Airway. Depressed ciliary activity and an ineffective cough lead to the accumulation of secretions. This may cause obstruction, particularly in the distal branches of the respiratory tree, leading to atelectasis and increased airway resistance. 
Lungs and pleura. Atelectasis may result from: (a) airway obstruction; (b) external compression of the lung by retractors during surgery or the pressure of air, blood, or chyle in the pleural cavity postoperatively; (c) alveolar collapse related to inhalation of 100 per cent oxygen or to changes in surfactant.

The inhalation of 100 per cent oxygen leads to the elimination of nitrogen from the alveoli. ${ }^{7}$ Because oxygen will diffuse more rapidly out of the alveoli than nitrogen, this may result in miliary atelectasis..$^{8}$

Surfactant, a substance present normally in the alveoli, is probably a lecithinprotein complex. It lowers surface tension and thus reduces the pressure required to maintain a given volume in the alveoli. A deficiency of surfactant results in increased surface tension with diminution of alveolar volume leading eventually to collapse. This process may occur following open-heart surgery with cardiopulmonary bypass. It has been demonstrated experimentally in the congestive collapse of the lungs which occurs following occlusion of one pulmonary artery. ${ }^{9}$ It may be a contributory cause of atelectasis which is not infrequently seen following a Blalock anastomosis. ${ }^{10}$

\section{Pulmonary Vascular Disease}

Cardiac patients with pulmonary hypertension are prone to the development of respiratory insufficiency in the postoperative period.

Pulmonary hypertension is present when the pulmonary artery pressure is above $30 / 15 \mathrm{~mm}$. Hg (Paul Wood). The formula pressure/flow = resistance correlates several important factors in relation to this entity. The pulmonary vascular bed has the ability to increase its capacity to three or four times without a simultaneous rise in pressure. ${ }^{11,12}$

During foetal life the pulmonary arterial walls are thick and pulmonary vascular resistance is high. Following birth, the pulmonary vascular resistance diminishes quite rapidly during the first few months and then more gradually until normal adult levels are reached. The presence of a systemic pulmonary shunt such as a large ventricular septal defect or patent ductus arteriosus is associated with increased pulmonary blood flow when the pulmonary vascular resistance falls. Anomalous pulmonary venous drainage also causes excessive pulmonary blood flow. This may cause hyperkinetic pulmonary hypertension. If the pulmonary blood flow becomes excessive during this period the infant may develop heart failure. A patent ductus arteriosus can be closed, or the pulmonary artery can be banded to reduce the shunt in a ventricular septal defect at this stage. Spontaneous diminution of size or closure of a ventricular septal defect or patent ductus arteriosus can take place and is accompanied by a regression of the hyperkinetic pulmonary hypertension. ${ }^{13,14}$ However, if neither change occurs, long-standing hyperkinetic pulmonary hypertension leads eventually to medial and intimal thickening in the pulmonary arteries. These pathological changes will increase the pulmonary vascular resistance and the pulmonary artery pressure will rise. This is fixed pulmonary hypertension. The vessels then become less responsive to the normal vasodilating effects of (a) an acetyl choline or tolazoline drip into the pulmonary artery; (b) the infusion of isopropyl noradrenaline 
("Isuprel"); or (c) the inhalation of high concentration of oxygen.15-17 Once this stage is reached, the prognosis for operative repair of the underlying defect becomes less favourable. ${ }^{18}$ The development of pathological change occurs at an earlier age when there is a transposition of the great vessels associated with a ventricular septal defect than where there is an isolated ventricular septal defect. ${ }^{19}$ In atrial septal defects pulmonary hypertension usually does not develop until adulthood. When respiratory insufficiency develops postoperatively, the resultant hypoxaemia and acidaemia cause pulmonary vasoconstriction and exaggerate the existing pulmonary hypertension..$^{15,10-21}$

\section{Diffusion}

Diffusion defects are caused by (a) the presence of fluid or exudates in the alveoli-for example, acute pulmonary oedema and pneumonia; (b) alveolar capillary thickening as produced by a chronic elevation of the left atrial pressure ${ }^{3}$ or in association with cardiopulmonary bypass.

It has been shown that following prolonged bypass some pulmonary congestion occurs which is associated with the deposition of polymorphonuclear leucocytes in the intima of the pulmonary vessels. This deposition is proportional to the length of the perfusion and the degree of haemolysis that occurs on the pump.22 Also, interstitial haemorrhage may result from sudden elevations of left atrial pressure if the left ventricle is unable to maintain the aortic pressure produced by the pump. This may occur especially during deep hypothermia with ventricular fibrillation or following removal of the aortic clamp. Increased bronchial flow, increased coronary flow, or an aortic pulmonary shunt while on total bypass increases the possibility of this occurrence.

It has been shown that following cardiac surgery the diffusion capacity is reduced by as much as 35 per cent on the first postoperative day, returning to normal in about 14 days. ${ }^{23}$ However, the hypoxaemia occurring in postoperative cardiac patients mainly results from disturbances of ventilation-perfusion relationships rather than from an oxygen diffusion defect. ${ }^{3}$

\section{Work of Breathing}

Many of the aetiological factors discussed above will lead to increased respiratory work and thus to an increased oxygen cost of breathing. Work is equal to force $X$ distance, and in gas mechanics, this corresponds to pressure $\times$ volume..$^{24}$ Thus, if airway resistance increases or compliance decreases, increased pressure will be required to produce the same tidal volume. Hence the work of breathing will be increased. The normal oxygen cost of breathing in an adult is about 2 per cent of the oxygen uptake. It is probably greater in neonates who have a more rapid respiratory rate and a lower lung compliance. Normal subjects breath at a rate and depth which is most economical in terms of respiratory work. In the infant at rest, this is about forty per minute. ${ }^{25}$ But postoperatively the rate and depth of respiration may be greatly altered, resulting in increased respiratory work. $25,20-28$

It has been shown that oxygen consumption increases postoperatively by as much as 30 per cent or more. Studies following heart surgery have demonstrated 
that in the quiet patient most of this increase is expended on the work of breathing, resulting from increased ventilatory demand and decreased respiratory efficiency. ${ }^{28}$

One may conclude that there are many factors in the postoperative cardiac patient which may increase the work of breathing and hence the oxygen consumption, and lead to respiratory insufficiency. Controlled ventilation will minimize these factors. Thus, many seriously ill patients may be successfully carried through the critical early postoperative period., ${ }^{20,30}$

\section{Postoperative Assessment of the Patient}

Following cardiovascular surgery, conditions may vary, from those patients with adequate ventilation, circulation, and acid-base balance to those with major disturbances of one or all of these parameters. The degree of disturbance depends on the following factors:

1. The length and degree of success of the surgical procedure.

2. The duration of cardiopulmonary bypass ${ }^{31}$ and/or the degree of hypothermia.

3. The presence or absence of pulmonary hypertension.

4. The time of circulatory insufficiency or cardiac arrest, if these occur.

Respiratory acidosis and hypoxaemia are associated with restlessness and tachypnoea, but these signs may not be present until the blood gas levels are grossly abnormal. ${ }^{20,32,33}$ The presence of cyanosis in a patient without polycythaemia is evidence of a severe degree of hypoxaemia. Accurate laboratory measurements of $\mathrm{P}_{\mathrm{O}_{2}}, \mathrm{P}_{\mathrm{CO}_{2}}$, and $\mathrm{pH}$ have made possible the detection of respiratory insufficiency in the early stages of its development and provides an accurate means of monitoring the results of treatment.

Acidaemia may be respiratory or metabolic in origin. Respiratory acidosis is always associated with an elevated $\mathrm{P}_{\mathrm{CO}_{2}}$ and may be corrected by assistance or control of ventilation. However, metabolic acidosis may be present with a $\mathrm{pH}$ that is low or nearly normal depending on whether the $\mathrm{P}_{\mathrm{CO}_{2}}$ is normal, elevated or lowered by hyperventilation. It is important to realize that accurate assessment of the patient's acid-base status requires directly or indirectly determined $\mathrm{pH}$ and $\mathrm{P}_{\mathrm{CO}_{2}}$ values. The base excess values may then be obtained from the SiggardAndersen Nomograms.

Hypoxaemia and/or diminished peripheral perfusion, usually the result of decreased cardiac output, may occur during the operative and postoperative period. This results in tissue hypoxia and the subsequent production of acid metabolites. Hypoxaemia and acidaemia directly effect the myocardium, decreasing contractility and increasing irritability. The cardiac output is further decreased, resulting in a further decrease in tissue perfusion and an increased production of acid metabolites. ${ }^{34,35} \mathrm{~A}$ vicious circle of events is thus set in motion.

The normal compensatory mechanisms for acidaemia include hyperventilation and the buffering systems, which are inefficient in the infant. Because of the horizontal position of the ribs, the infant is unable to increase his tidal volume appreciably and any increase in effective alveolar ventilation must be produced by the inefficient method of increasing respiratory rate. Thus ventilatory control 
is an effective compensatory mechanism, especially for patients in this age group. The buffering capacity of the patient may be supplemented by the administration of sodium bicarbonate or THAM. It must be emphasized, however, that the ultimate goal is the prevention of metabolic acidosis by improvement of peripheral tissue perfusion and oxygenation.

\section{Indications for Assisted Ventilation Following Cardiac Surgery}

It is apparent that controlled ventilation can reduce the number of factors that contribute to the development of postoperative respiratory insufficiency. It would seem logical to consider instituting this treatment prophylactically in the more seriously ill patients. Following are the indications for assisted ventilation:

1. Inadequate ventilation from any cause leading to hypoxaemia and hypercarbia..$^{4,86}$

2. Relief of respiratory work, particularly when breathing is laboured or very rapid and shallow. ${ }^{28-30}$

3. Periods of cardiopulmonary bypass longer than one to one and half hours.

4. Moderate or severe pulmonary hypertension with an associated increase in pulmonary vascular resistance.

5. Severe left heart failure.

\section{The Advantages of Assisted Ventilation}

1. A reduction in the number of detrimental factors during the critical early postoperative period.

2. Reduction in the degrees of atelectasis resulting in an improved ventilationperfusion balance.

3. A reduction in the work of breathing and thus the oxygen-cost of breathing.

4. A reduction in post-thoracotomy pain.

5. The administration of accurately controlled oxygen concentrations is facilitated.

6. Ability to maintain arterial $\mathrm{P}_{\mathrm{OO}_{2}}$ within normal limits.

7. Facilitation of suctioning by the presence of a naso-tracheal tube or tracheotomy.

\section{The Management of Ventilation}

Intubation. In patients requiring short term ventilatory control, naso-tracheal intubation is frequently employed in preference to tracheotomy.

Prolonged laryngeal intubation with silver tubes was first used in the management of diphtheria. ${ }^{37,38}$ Nasotracheal intubation in children has become widely employed since 1963. The interest in the technique received considerable stimulus from recent reports in the literature..$^{30-42}$ At The Hospital For Sick Children, Toronto, it had been employed in postoperative cardiovascular patients since 1961, but its use has now been greatly expanded. In 1965, about one hundred and sixty children have been intubated by the naso-tracheal route for the management of many conditions. It is a useful technique for short-term assisted or controlled ventilation, and as an intermediate step in cases where post-tracheotomy decanulation presents a problem. ${ }^{43}$ It offers advantages over early tracheotomy for the following reasons:

1. Naso-tracheal intubation is a relatively simple technique. 
2. An additional surgical procedure (tracheotomy) and its complications may be avoided. ${ }^{44-18}$

3. It can remain in position for prolonged periods with a low incidence of complications.

With both tracheotomy and nasal intubation, expert nursing care, a wellsupervised program of chest physiotherapy, and a careful sterile suction technique are essential if the expected results are to be achieved.

Possible complications of nasal intubation are listed below:

1. Transient hoarseness or a laryngeal oedema may occur following extubation. Prophylactic steroid coverage is now given routinely for 24 hours to minimize the development of swelling or oedema.

2. Granulomata of the vocal cords, which usually disappear within three to six months, have been reported. ${ }^{40}$

3. In common with tracheotomy: (a) the normal method of humidification of the inspired gas is eliminated, and there is interference with the normal ciliary activity. (b) Accidental extubation, endobronchial intubation, or obstruction of the tube may occur. (c) The occurrence of subglottic stenosis in two to four per cent of cases. ${ }^{30,40,49,60}$ This has occurred in periods as short as five days or as long as 43 days of intubation. Several papers report patients in whom the subglottic stenosis has regressed after several months.,49

In summary, nasotracheal intubation has a useful place in respiratory management, particularly when short-term ventilation is necessary.

The incidence of complications and the recommended period of intubation are currently under review in this hospital, ${ }^{51}$ One hundred and sixty patients were reviewed in 1965. There were four confirmed cases reported with subglottic tracheal stenosis and one questionable case. The duration of the intubation period varied. In three of four cases, stenosis followed intubation from three to five days. The fourth case was an infant with a ventricular septal defect, who had been intubated for 43 days.

In contrast, a one-month infant with severe tetanus was curarized and ventilated for twenty-eight days through a naso-tracheal tube. The only complication following extubation was a temporary hoarseness.

Currently, the majority of cardiovascular patients requiring ventilatory assistance for more than two to three days have a tracheotomy done at that time.

Humidification. Nasotracheal intubation and tracheotomy bypass the normal mechanism for humidification of inspired gases. To prevent drying of the respiratory tract and inspissation of secretions, it is essential to humidify the gases prior to delivery to the patient.

Efficient humidification is related to particle size. ${ }^{62}$ The smaller the droplet in diameter the further it will travel down the tracheobronchial tree. Droplets of 30-micron diameter tend to settle in the trachea. Those of 10-micron diameter reach the terminal bronchioles and alveolar ducts, while those of 0.5- to 3-micron diameter reach the alveolar sacs. Particles of 0.5 -micron diameter have the least tendency to deposit in the respiratory tract because particles of this size tend to follow air currents, and their motion is little affected by molecular bombardment.

A knowledge of the droplet size characteristics is thus important in selecting a humidifier. Uniformity of droplet size is also important. Particles of equal size 
have equal charges and thus form a more stable mist which will produce a higher relative humidity in the inspired gas. ${ }^{53}$ The different principles employed in producing microdroplet vapour have recently been reviewed..$^{54}$

In addition to the use of efficient means of humidification of the inspired air to avoid crusting of secretions, the patient's fluid requirements must be maintained. If crusting does occur, $1 / 2$ to $2 \mathrm{cc}$. of saline, depending on the size of the patient, may be instilled into the tube every half to one hour to facilitate suctioning.

Ventilation and ventilators. During normal respiration, there is a negative inspiratory and a positive expiratory intrathoracic pressure. This results in a low mean intrathoracic pressure. Intermittent positive pressure respirators produce a positive inspiratory pressure and thus increase mean intrathoracic pressure. This reduces venous return to the right side of the heart, which may be detrimental to a patient who is hypovolaemic or has an unstable circulation such as may exist following cardiac surgery. The mean intrathoracic pressure can be reduced by (a) using a short rapid inspiration with a relatively longer expiratory pause (however, gaseous distribution is usually uneven, with a short inspiratory phase);

INTRA PULMONARY PRESSURE PATTERNS

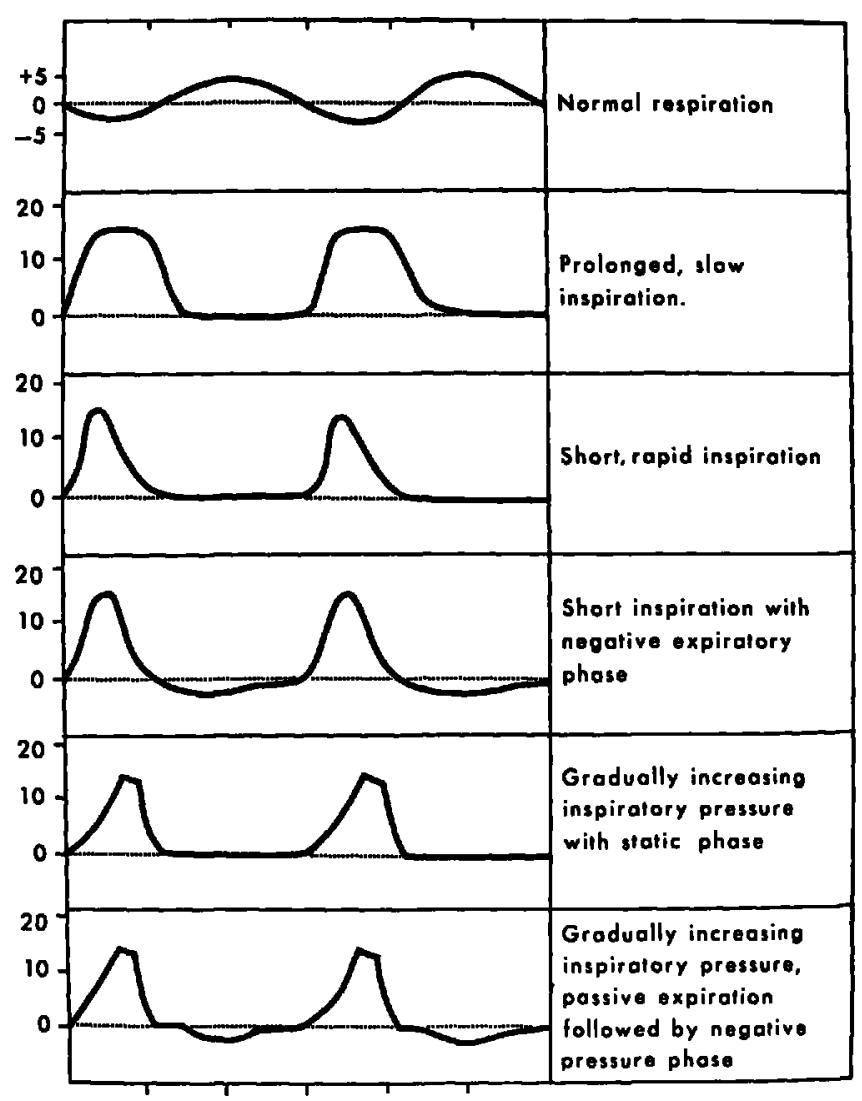

Figure 1 
(b) the incorporation of a negative phase during expiration; (c) employing a respirator with an increasing force generator which produces a gradually increasing gas-flow rate.

Ventilators augment or replace the patient's own respiratory efforts when attached to his airway. An assistor will inflate in response to an inspiratory effort by the patient while a controller will cycle automatically.

With pressure-controlled ventilators the pressure is adjusted to provide a suitable tidal volume. A pressure-controlled ventilator will respond to changing resistance by reciprocally changing the amount of gas it forces into the patient. It thus requires frequent adjustment to produce optimal ventilation. If a pressurecycled ventilator cannot achieve the maximum inspiratory pressure it will stall in inspiration unless it has a time-cycling mechanism which limits the duration of inspiration. The Bird Mark VIII is used successfully in many postoperative cardiac surgical patients. It is a pressure-controlled, time-cycled assistor controlled with a venturi for the production of a negative pressure phase.

The volume-controlled ventilator discharges a predetermined volume of gas during each inspiratory phase. As long as it has adequate reserve power to deliver its predetermined volume, it will overcome increased resistance and deliver the same tidal volume under higher pressure. Any leakage from the airway, however, will result in a loss of tidal volume, and increases in the resistance to inflation will increase the leak. ${ }^{55,56}$ When compliance is high and airway resistance is low, either type of ventilator can be used, but when compliance is low and airway resistance is high a volume-controlled, piston-driven respirator with plenty of reserve power will be necessary to produce adequate ventilation.

The Engstrom respirator has several features which make it most satisfactory for ventilating postoperative cardiac patients. $29,57-59$

1. The pressure-flow characteristics permit the most efficient gaseous distribution in the lungs with the lowest mean intrathoracic pressure and least interference with venous return. This is achieved by gradually increasing the gas flow rate. The initial low flow rate permits air to enter even relatively constricted bronchioles. Once the dynamic gas phase has begun with low flow, the increasing gas flow produces ventilation in all areas. By contrast, respirators which have a rapid initial flow rate over-ventilate areas of the lung with low resistance at the expense of areas with high resistance. Peak inspiration is followed by a static phase when the compressed gases in the circuit outside the lungs enter the more slowly filling alveoli equalizing the pressure in the alveoli. The inspiratory phase constitutes one-third of the total respiratory cycle.

2. The Engstrom respirator is constructed with two systems in series. The piston drives gas which enters a plexiglass cylinder and compresses the bag containing an adjusted volume of gas which is delivered to the patient. Thus there are (a) the driving gas and (b) the patient's respiratory gas systems. This arrangement allows very high pressures and hence greater power to be applied to the gas being delivered to the patient without exposing the patient directly to these high pressures. The actual airway pressure depends on the compliance and resistance of the patient's respiratory apparatus and on the 
controlled volume being added during each cycle to the bag in the patient's circuit.

Increasing the external pressure on the bag will lengthen the static phase because the inspiratory flow rates are accelerated. Ideally, the static phase should last 0.2 to 0.4 seconds. This is long enough to produce even distribution without causing an undesirable rise in intrathoracic pressure.

3. The patient is in direct communication with the bag. Spontaneous breathing between inspiratory phases of the respirator temporarily subtracts from the next tidal volume in the reservoir bag. However, when the inspiratory phase occurs this is added to the diminished tidal volume from the reservoir bag so that the patient receives a constant tidal volume. When a patient is ventilated with a respirator without a secondary system the extra gas inhaled from an out-of-phase breath is added to the tidal volume delivered by the respirator at the next inspiration tending to produce hyperinflation.

4. A negative pressure phase can be produced, if desired, by a venturi system. It follows an initial passive expiratory period that prevents the bronchial collapse and air trapping which occur if the negative pressure is applied at the beginning of expiration.

5. Inspiratory pressure, tidal volume, and frequency can be monitored on the machine.

6. The minute volume and oxygen concentration can be controlled.

\section{Review of cases}

The cardiovascular procedures carried out at The Hospital for Sick Children during 1965 are shown in Table II. The percentage of postoperative cardiac patients who required assisted or controlled ventilation and the percentage of

TABLE II

Cardiac Vascular Operations, 1965

\begin{tabular}{|c|c|c|c|c|}
\hline Congenital anomaly & Procedure & $\begin{array}{l}\text { Total } \\
\text { no. of } \\
\text { cases }\end{array}$ & $\begin{array}{c}\% \\
\text { Ventilated }\end{array}$ & $\begin{array}{c}\% \\
\text { Ventilated } \\
\text { surviving }\end{array}$ \\
\hline \multirow[t]{2}{*}{$\begin{array}{l}\text { Tetrology of Fallout } \\
\text { T.G.V. }\end{array}$} & \multirow{2}{*}{$\left.\begin{array}{l}\text { Total correction } \\
\text { Mustard Baffle } \\
\text { Creation ASD } \\
\text { Blalock-Hanlon }\end{array}\right\}$} & $\begin{array}{l}34 \\
14\end{array}$ & $\begin{array}{l}53 \\
69\end{array}$ & $\begin{array}{l}83 \\
44\end{array}$ \\
\hline & & 18 & 50 & 42 \\
\hline $\left.\begin{array}{l}\text { Tetrology of Fallot } \\
\text { TGV }\end{array}\right\}$ & $\begin{array}{l}\text { Blalock } \\
\text { Potts } \\
\text { Glenn } \\
\text { Glenn and Creation ASD }\end{array}$ & $\begin{array}{r}98 \\
10 \\
5 \\
1\end{array}$ & $\begin{array}{r}7 \\
30 \\
40 \\
100\end{array}$ & $\begin{array}{r}17 \\
33 \\
100 \\
0^{*}\end{array}$ \\
\hline $\begin{array}{l}\text { T.A.P.V.D. } \\
\text { P.A.P.V.D. } \\
\text { V.S.D. }\end{array}$ & $\begin{array}{l}\text { Correction } \\
\text { Correction } \\
\text { Closure } \\
\text { P.A. banding }\end{array}$ & $\begin{array}{r}9 \\
10 \\
29 \\
10\end{array}$ & $\begin{array}{l}80 \\
10 \\
42 \\
80\end{array}$ & $\begin{array}{r}75 \\
100 \\
45 \\
12\end{array}$ \\
\hline Pulmonary Stenosis & $\left.\begin{array}{l}\text { Valvotomy } \\
\text { Infundibulectomy }\end{array}\right\}$ & 27 & 23 & 33 \\
\hline $\begin{array}{l}\text { Aortic Stenosis } \\
\text { Patent Ductus Arteriosus } \\
\text { A.S.D. } \\
\text { A.S.D. and Anomalous I.V.C. } \\
\text { Coarctation of Aorta }\end{array}$ & $\begin{array}{l}\text { Valvotomy, etc. } \\
\text { Ligation } \\
\text { Closure } \\
\text { Coarctectomy }\end{array}$ & $\begin{array}{r}17 \\
74 \\
43 \\
1 \\
27\end{array}$ & $\begin{array}{r}6 \\
1 \\
2 \\
100 \\
22\end{array}$ & $\begin{array}{r}100 \\
0 \\
100 \\
100 \\
33\end{array}$ \\
\hline
\end{tabular}

-Late death. 
those surviving are listed. The over-all low survival rate in the group requiring ventilation is indicative of the serious condition of many of these patients. The largest group ventilated was composed of those patients who underwent a total correction of Tetralogy of Fallot. Most of these patients were ventilated for the first 24 to 36 postoperative hours. The next most common group consisted of those having closure of a ventricular septal defect associated with pulmonary hypertension. Patients having a Mustard Bafle procedure for Transposition of the Great Vessels, ${ }^{60}$ the creation of an atrial septal defect, ${ }^{61}$ or correction of total anomalous pulmonary venous drainage $e^{82,63}$ usually required assisted ventilation for the first three or four days. A selection of six case histories is presented to illustrate some of the previously noted indications for postoperative assisted or controlled ventilation.

\section{Case 1}

K.D. was a six-year-old, moderately cyanosed, with a Tetralogy of Fallot. A total correction of the infundibular stenosis and closure of a $12 \mathrm{~mm}$. ventricular septal defect was carried out during an 82-minute cardiopulmonary bypass (oesphageal temperature $25^{\circ} \mathrm{C}$.). Immediately postoperatively, a naso-tracheal tube was inserted and ventilation was instituted on a prophylactic basis. Twelve hours postoperatively, satisfactory arterial oxygen and carbon dioxide tensions were being maintained during periods of spontaneous ventilation. These periods were gradually lengthened, and ventilation was discontinued in the twentieth postoperative hour.

\section{Case 2 (Fig. 2)}

A.M. was a nine-year-old girl with partial anomalous pulmonary venous drainage. During a 90-minute period of cardiopulmonary bypass an atrial septal defect was created and a baffle formed to correct the anomalous venous drainage. Postoperatively, during a trial period of spontaneous ventilation, the $\mathrm{P}_{\mathrm{O}_{2}}$ fell to

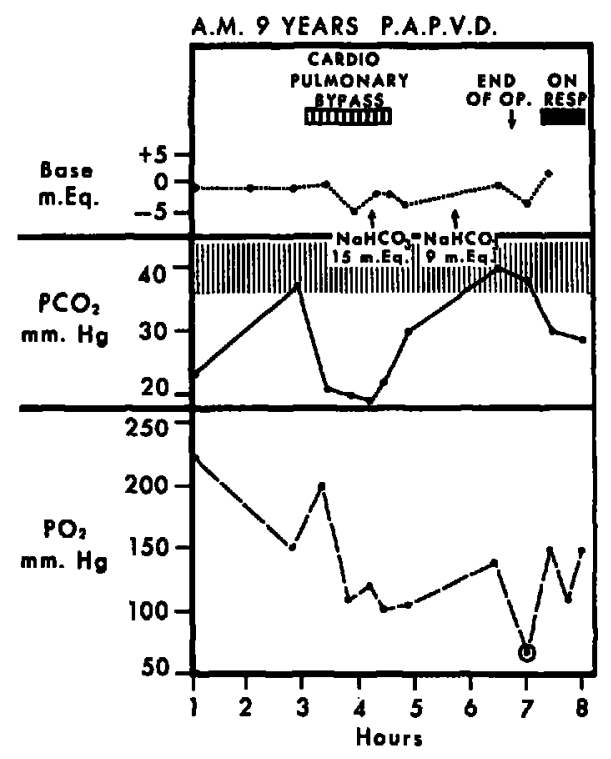

FIGURE 2 
$70 \mathrm{~mm}$. and she became restless. A naso-tracheal tube was inserted and controlled ventilation was initiated. The restlessness disappeared and the $P_{O_{2}}$ was maintained at satisfactory values. On the second postoperative day, ventilatory assistance was discontinued without difficulty.

\section{Case 3 (Fig. 3)}

P.K, a seven-year-old girl with Tetralogy of Fallot, had a non-functioning Blalock Anastomosis. A total correction was carried out during the 111-minute cardio-pulmonary bypass (at oesophageal temperature of $31^{\circ}$ C.). On her return to the recovery room, there was no evidence of restlessness, and the $\mathrm{P}_{\mathrm{O}_{2}}$ was $150 \mathrm{~mm}$. $\mathrm{Hg}$. The arterial $\mathrm{P}_{\mathrm{CO}_{2}}$ was, however, $55 \mathrm{~mm}$. $\mathrm{Hg}$, and controlled ventilation was initiated through a naso-tracheal tube.

The following morning a 20-minute trial period of spontaneous ventilation resulted in hypoxaemia $\left(\mathrm{P}_{\mathrm{O}_{2}} 46 \mathrm{~mm} . \mathrm{Hg}\right)$ and hypercarbia $\left(\mathrm{P}_{\mathrm{CO}_{2}} 62 \mathrm{~mm} . \mathrm{Hg}\right)$. On the second postoperative day, periods of spontaneous ventilation were gradually increased and assistance was discontinued on the third day.

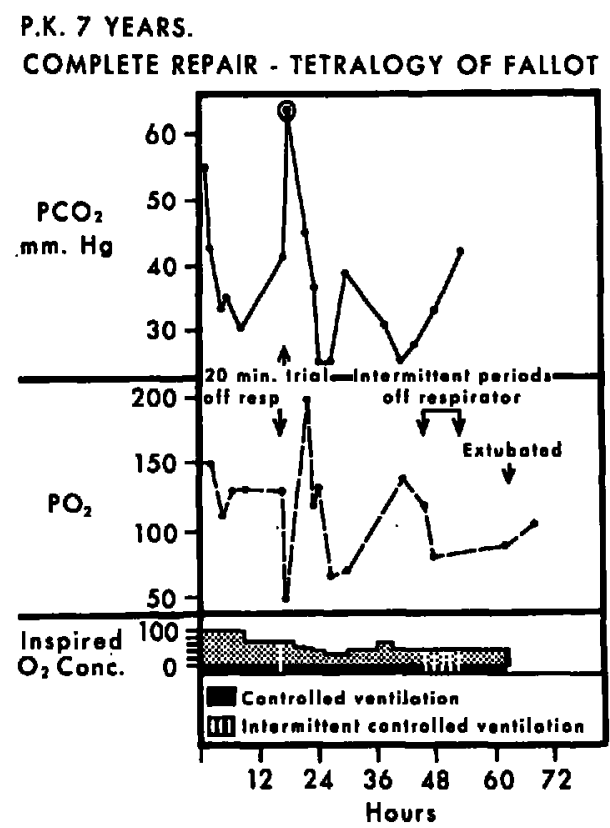

Frgure 3

\section{Case 4 (Fig. 4)}

D.B., a two-year-old male, had a ventricular septal defect with hyperkinetic pulmonary hypertension. His pulmonary artery pressure was $55 / 19 \mathrm{~mm}$. $\mathrm{Hg}$, with a pulmonary-systemic vascular resistance ratio of $1: 6$ and a flow ratio of 2.8:1. The defect was closed with a $15 \times 10 \mathrm{~mm}$. patch during a 31-minute cardiopulmonary bypass.

Postoperatively, following a three-minute trial of spontaneous ventilation, the $P_{\mathrm{O}_{2}}$ fell to $66 \mathrm{~mm}$. Hg. This supported the decision to ventilate the patient because of his pulmonary hypertension. Artificial ventilation was discontinued 
after forty hours, following trial periods of spontaneous ventilation which were well tolerated.

In Figure 5, note the inspiratory pressures and tidal volumes, measured on the Engstrom Respirator, which demonstrate the higher inspiratory pressure required initially. Later as compliance improved, the inspiratory pressure required to maintain adequate ventilation could be reduced.

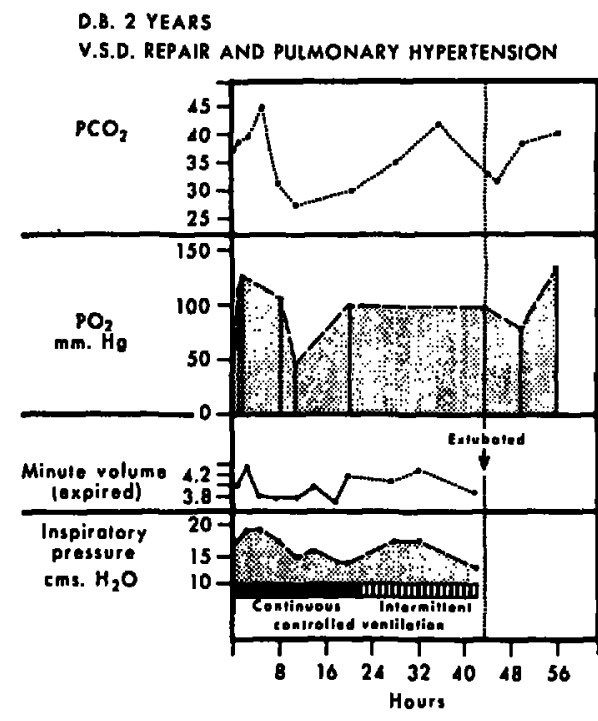

Figure 4

\section{Case 5 (Fig. 5)}

P.P., a 13-month-old boy with tetralogy of Fallot and cardiac failure, had a Blalock Anastomosis. Postoperatively the cardiac failure increased during the subsequent five days. Tracheotomy was performed on the fifth day to facilitate tracheobronchial suction, and ventilatory assistance was initiated. There was a large air leak around the tracheotomy tube, resulting in hypoventilation and respiratory acidosis. Larger tracheotomy tubes were inserted on two occasions. Subsequently, a dehisance of the tracheotomy wound developed. The pressurecontrolled time-cycled ventilator was unable to compensate fully for the leak. The cardiac failure progressively worsened. It was decided on the twelfth day to perform a banding of the Blalock Anastomosis because the shunt was too large. The patient expired on the fifteenth day.

\section{Case 6 (Fig. 6)}

A.K. was a five-year-old girl with transposition of the great vessels without a ventricular septal defect. A large atrial septal defect had been created at the age of two years. This resulted in improvement of her colour and general condition. During the six months prior to surgery, her condition had gradually deteriorated, and dyspnoea and cyanosis had increased. During a 122-minute period of cardiopulmonary bypass at $29-30^{\circ} \mathrm{C}$, a Mustard Baffle procedure was carried out. ${ }^{19,60}$ In the postoperative period, ventilation was controlled for two days. 
P.P. 13 MONTHS TETRALOGY OF FALLOT

POST OP. CARDIAC FAILURE AND RESPIRATORY INSUFFICIENCY

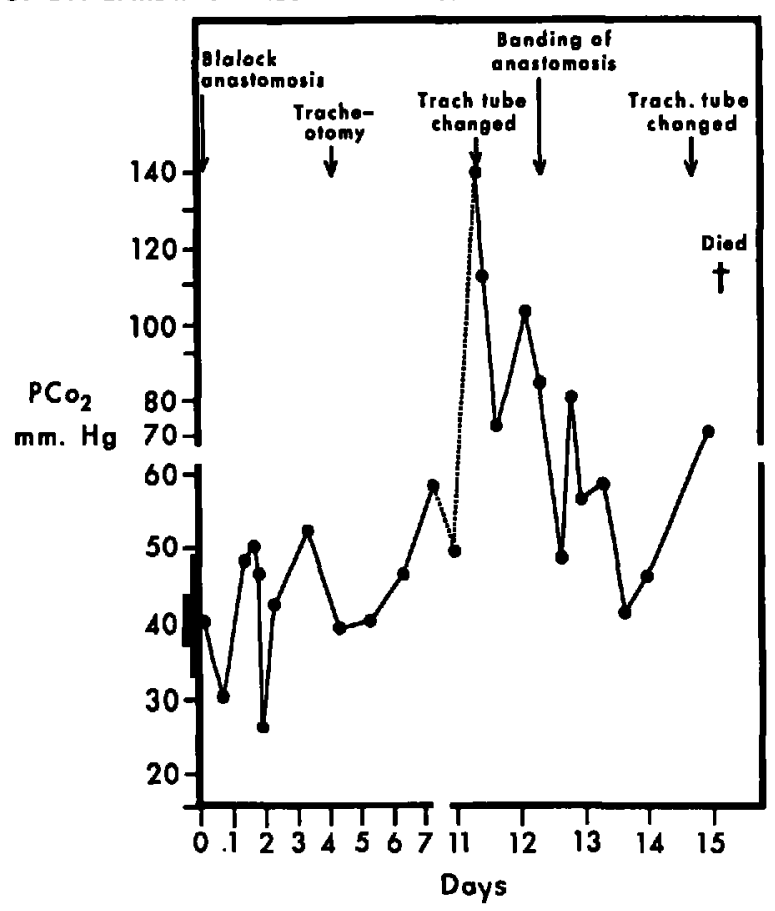

Figure 5

COURSE OF PATIENTS FOLLOWING TOTAL CORRECTION OF TRANSPOSITION OF GREAT VESSELS

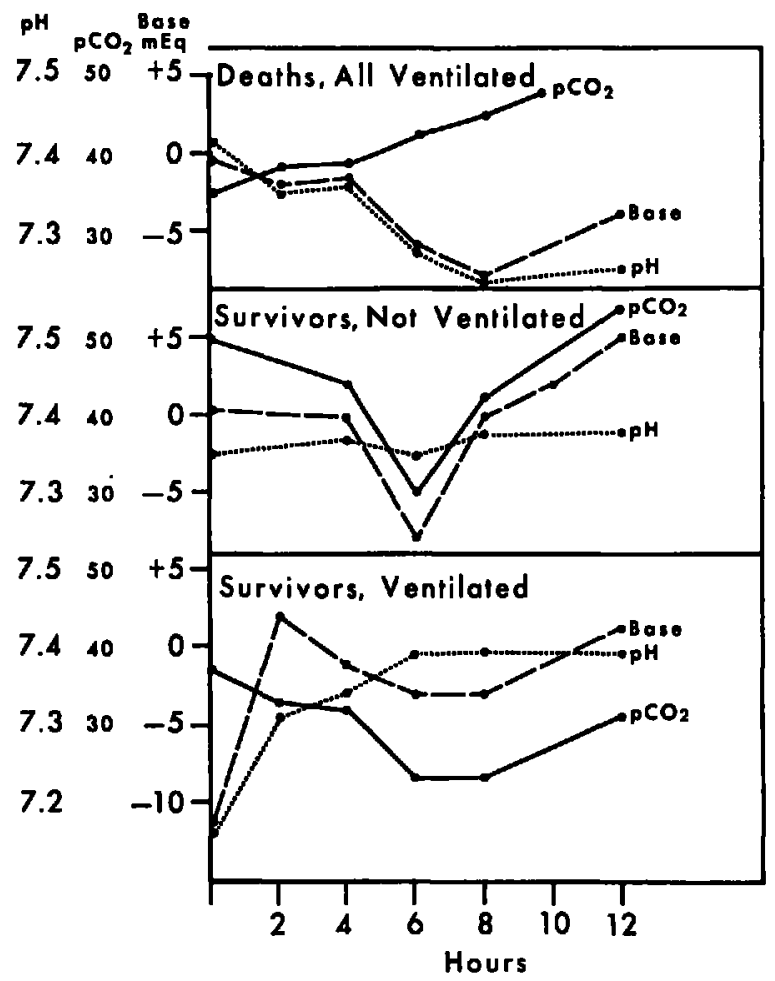

Frgure 6 
During the initial trial periods of spontaneous ventilation the patient developed hypercarbia. After a normal $\mathrm{P}_{\mathrm{CO}_{2}}$ had been maintained during several hours of spontaneous ventilation, extubation was carried out.

Figure $7^{84}$ shows the average course of twenty-one patients having the Mustard Baffle procedure for transposition. ${ }^{60,65}$ The nine non-survivors, all of whom were ventilated, all had moderate or severe pulmonary hypertension. In the surviving group without hypertension, six were ventilated. The six not ventilated developed $\mathrm{P}_{\mathrm{CO}_{2}}$ in the $50 \mathrm{~mm}$. $\mathrm{Hg}$ range. The development of metabolic acidosis four to eight hours postoperatively is noted in the non-surviving group and the non-ventilated survivors.

\section{A.K. 5 YEARS}

TOTAL CORRECTION T.G.V. (MUSTARD PROCEDURE)

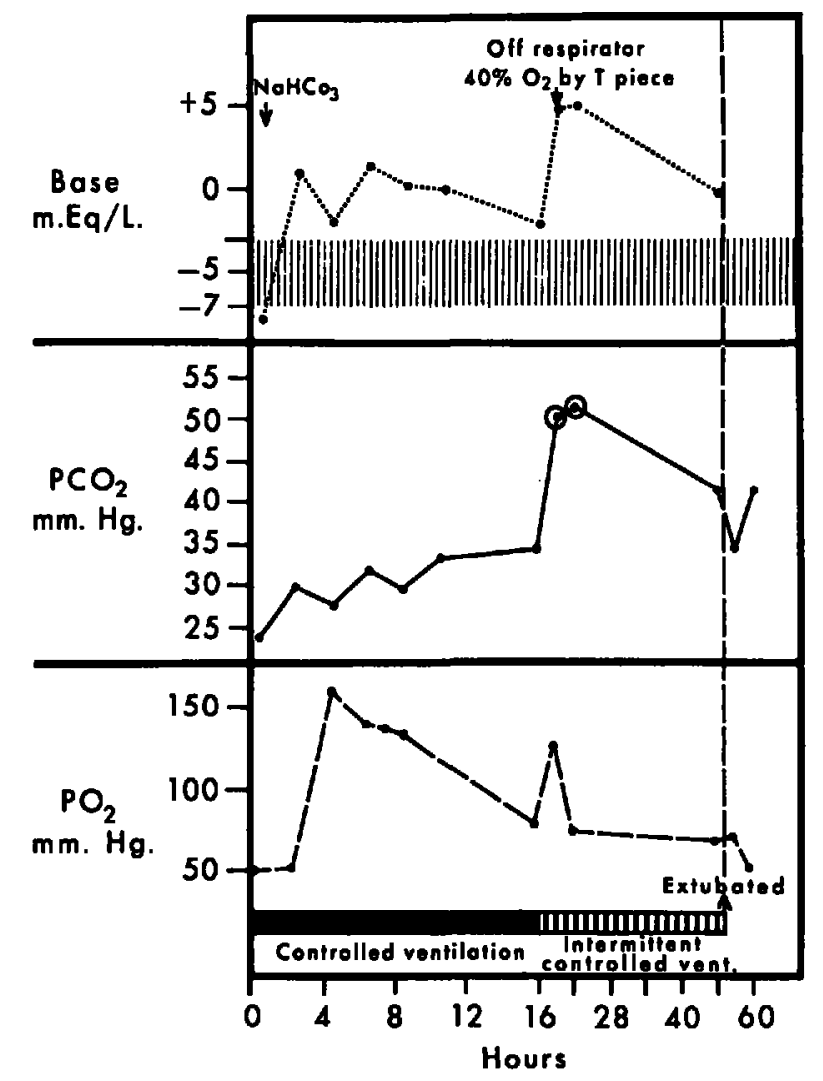

Figure 7

\section{SUMMary}

The indications for ventilatory assistance in postoperative paediatric cardiovascular patients have been reviewed. The use of naso-tracheal intubation, the preferred respirator characteristics, and the importance of humidification have been discussed.

In the postoperative cardiovascular patient with borderline cardiopulmonary reserve, a period of controlled ventilation is important in the prevention of postoperative morbidity and mortality. Naso-tracheal intubation is an excellent 
technique in the management of short-term ventilatory control. Six case reports are used to illustrate some of the indications for assisted ventilation and problems in management.

\section{RÉSUMÉ}

Nous avons passé en revue les facteurs qui peuvent causer de l'insuffisance respiratoire chez les cardiaques, dans la période postopératoire.

La condition postopératoire du malade dépend des facteurs suivants:

1. La durée de la réussite de l'opération.

2. La durée de la circulation extra-corporelle et/ou le degré d'hypothermie.

3. La présence ou l'absence d'hypertension pulmonaire.

4. Le moment de l'insuffisance circulatoire ou de l'arrêt cardiaque, s'ils se produisent.

Nous insistons sur l'importance de corriger l'acidose respiratoire et métabolique à l'aide de la ventilation controlée et d'agents correcteurs. Le but principal cependant est la prévention de l'acidose métabolique en améliorant la perfusion tissulaire périphérique et l'oxygénation.

Les indications de la ventilation assistée sont:

1. Une ventilation insuffisante, quelle qu'en soit la cause, pouvant conduire à l'hypoxémie et à l'hypercapnée.

2. L'assistance au travail respiratoire, surtout lorsque la respiration est laborieuse, très rapide et superficielle.

3. Une durée de plus d'une heure ou une heure et demie de circulation extracorporelle.

4. Une hypertension pulmonaire moyenne ou sérieuse associée à une augmentation de la résistance vasculaire pulmonaire.

5. Une grave défaillance du cour gauche.

Les avantages de la ventilation assistée sont:

1. Une diminution du nombre de facteurs nocifs durant cette phase critique du début de la période postopératoire.

2. Une diminution du degré d'atélectasie, ce qui amène une amélioration du rapport ventilation-perfusion.

3. Une diminution du travail de la respiration et aussi une diminution de la consommation d'oxygène.

4. Une diminution de la douleur consécutive à la thoracotomie.

5. L'administration de concentrations d'oxygène contrôlées de façon précise est plus facile.

6. $\mathrm{La} \mathrm{P}_{\mathrm{CO}_{2}}$ artérielle peut être maintenue dans les limites normales.

7. La succion est rendue plus facile par la présence d’un tube naso-trachéal ou d'une trachéotomie.

L'intubation naso-trachéale est utile pour la ventilation assistée ou contrôlée durant une période peu prolongée ou encore comme technique intermédiaire lorsqu'on craint que la décanulation ne pose des problèmes après la trachéotomie.

Ses avantages sur la trachéotomie précoce sont les suivants:

1. L'intubation nasale est une technique relativement simple. 
2. Elle permet d'éviter une nouvelle opération (la trachéotomie) et ses complications.

3. Elle peut être laissée en place assez longtemps car ses complications sont peu fréquentes.

Si l'on veut obtenir les résultats désirés, la trachéotomie et l'intubation nasale doivent être complétées par les soins attentifs d'un personnel compétent, un programme bien suivi de physiothérapie thoracique, et une bonne technique de succion aseptique.

Les complications possibles de l'intubation nasale sont:

1. Enrouement passager ou œdème laryngé.

2. Granulôme des cordes vocales.

3. Complications communes à l'intubation nasale et à la trachéotomie:

$a$. Altération de l'humidification et de l'activité ciliaire. tube.

b. Extubation accidentelle, intubation endo-bronchique, ou obstruction du

c. Sténose sous-glottique.

Généralement la plupart des cas de chirurgie cardio-vasculaire qui requièrent une ventilation assistée durant plus de deux ou trois jours subissent alors une trachéotomie.

Nous parlons dans ce travail de l'importance d'une humidification appropriée et d'une connaissance exacte des caractéristiques du ventilateur utilisé.

Le groupe le plus important de malades ventilés en période postopératoire comportait ceux qui subissaient une correction totale de tétralogie de Fallot. La plupart ont été ventilés durant les premières 24 à 36 heures après l'opération. Le groupe suivant comprenait ceux qui souffraient d'une défectuosité de la cloison ventriculaire associée à une hypertension pulmonaire. Les malades qui subissent l'opération "Mustard Baffle" pour la transposition des gros vaisseux, la correction d'un défaut septal auriculaire, ou la correction d'un drainage complet veineux pulmonaire anormal, tous ces malades requièrent habituellement une ventilation assistée au cours des trois ou quatre premiers jours.

\section{ACKNowledGements}

The authors wish to thank Dr. W. T. Mustard and Dr. G. Trusler for permission to review their cases, and Dr. Mustard for his criticism and encouragement. They also extend their thanks to Dr. M. J. A. Blackwood and Dr. Wm. McJannett and the Recovery Room Nursing Staff for their help with the collection of data.

\section{REFERENCES}

1. Lassen, H. C. A. A Preliminary Report on the 1952 Epidemic of Poliomyelitis in Copenhagen with Special Reference to the Treatment of Acute Respiratory Insufficiency. Lancet 1: 37 (1953).

2. Cherniak, R. M. \& Chemniar, L. Respiration. Philadelphia: W. B. Saunders (1961).

3. Campber., E. J. M. Respiratory Failure. Brit. Med. J. I: 1451 (1965).

4. Fairley, H. B. \& Chandrens, R. A. Management of the Patient with Respiratory Insufficiency. Canad. Anaesth. Soc. J. 7: 447 (1960).

5. Bromace, P. Pain and Its Management (paper presented at Western Biennial Conference on Anaesthesiology, Vancouver, 1964). 
6. Parbrook, G. D.; Rees, G. A. D.; \& Robertson, G. S. Relief of Post Operative Pain: A Comparison of a 25\% Nitrous Oxide and Oxygen Mixture with Morphine. Brit. Med. J. II: 480 (1964).

7. Comroe, J. H. Physiology of Respiration. Chicago: Year Book Publishers. (1965), pp. 105-111.

8. Déry, R.; Pelletere, J.; Jacques, A.; Claver, M.; \& Houde, J.; Alveolar Collapse Induced by Denitrogenation. Canad. Anaesth. Soc. J. 12: 531 (1965).

9. Clements, J. A. Surfactant in Pulmonary Disease. New England J. Med. 272, No. 25 (1965).

10. Sloni, I. A. Personal communication.

11. Rushmer, R. F. Cardiovascular Dynamics. Philadelphia: W. B. Saunders (1961).

12. Edwards, J. E. Functional Pathology of the Pulmonary Vascular Tree. Circulation 15: 164 (1957).

13. ARcilla, R. A. Further Observations of the Natural History of Isolated V.S.D. in Infancy and Childhood. Circulation 28: 560 (1963).

14. Shaher, R. M.; Fowlen, R. S.; KmD, B. S. L.; Moes, C. A. F.; \& Keith, J. D. Spontaneous Closure of a Ventricular Septal Defect in a Case of Complete Transposition of the Great Vessels. Canad. M. A. J. 93: 1037 (1965).

15. Sloan, I. A. \& Furman, E. B. Anaesthesia for Total Correction of Transposition of the Great Vessels. (In press.)

16. Fritrs, H. W.; Harris, P.; Claus, R. H; Odell, J. E.; \& Cournand, A. Effect of Acetyl Choline on the Human Pulmonary Circulation under Normal and Hypoxic Conditions. J. Clin. Invest. 37: 99 (1958).

17. KurkuIN, J. W.; Devloo, R. A.; \& Wemman, W. H. Intracardiac Repair for Transposition of the Great Vessels. Surgery 50: 28 (1961).

18. Mustard, W. T. Personal communication.

19. Mustard, W. T.; Kerth, J. D.; Truslen, G .A.; Fowler, R.; \& KIDD, L. Surgical Management of Transposition of the Great Vessels. J. Thoracic \& Cardiovasc. Surg. 48; 953 (1964).

20. Bencotsky, E. H.; Lehr, D. E.; \& Fistman, A. P. The Effects of Changes in Hydrogen Ion Concentration on the Pulmonary Circulation. J. Clin. Investigation 41: 1492 (1962).

21. Bercofsky, E. H.; Bass, B. G.; Ferretti, R.; \& Fismuan, A. P. Pulmonary Vasoconstriction in Response to Precapillary Hypoxaemia. J. Clin. Investigation 42: 1201 (1963).

22. Kontaxus, A.; Tomn, R.; Witters, B.; Neville, W. E.; \& Clowes, T. H. A. Pulmonary Changes Secondary to Prolonged Perfusion. Surg. Forum 12: 52 (1961).

23. Ellison, L. T.; NIx, A. R.; \& Ellison, R. G. Pulmonary Membrane Injury During Surgery. Surg. Forum 12: 50 (1961).

24. Engstrom, C. G. \& Nonlander, O. P. A New Method for Analysis of Respiratory Work by Measurement of the Actual Power as a Function of Gas Flow: Pressure and Time. Acta. Anaesth. Scandinav. 6: 49 (1962).

25. SWYer, P. R., \& Wright, J. J., "Ventilation and Ventilatory Mechanics in the Newborn". J. of Pediatrics 56: 612 (1960).

26. McIlroy, M. B.; Marshall, R.; \& Christy, R. V. The Work of Breathing in Normal Subjects. Clin. Sc. 13: 127 (1954).

27. Bartuet, R. G. Oxygen Cost of Breathing. J. Appl. Physiol. 12: 413 (1958).

28. Thung, N. S.; Herzoc, P.; Christlene, I.; Dammann, J. F.; Thompson, W. M.; \& WEBB, M. The Cost of Respiratory Effort in the Postoperative Cardiac Patient. Circulation 33: 552 (1963).

29. Dammann, J. F.; Thung, N. S.; Christlem, II.; Littlefield, J. B.; \& Muller, W. M. The Management of the Severely Ill Patient after Open Heart Surgery. J. Thoracic \& Cardiovasc. Surg. 45: 80 (1963).

30. Dammann, J. F. The Importance of Controlled Ventilation Following Open Heart Surgery. Int. Anaes. Clinics. 2 : 55 (1963).

31. Raison, J. C. A. Acid Base Changes and Tissue Respiration in Extracorporeal Circulation. Ann. R.C. Surg. (Eng.) 37: 93 (1965).

32. Spencer, S. C.; Vincent, D. W.; Lru, W. C.; \& Bannson, H. T. The Use of a Mechanical Respirator in the Management of Respiratory Insufficiency Following Trauma or Operation for Cardiac or Pulmonary Disease. J. Thoracic Surg. 36: 729 (1958).

33. Hood, R. M.; Beall, A. C.; \& Gerbode, F. A. Hypoventilation Hypoxia and Acidosis Occurring in the Acute Post-Operative Period. J. Thoracic Surg. 36: 729 ( 1958). 
34. Holmdahl, M. H. The Effect of Inadequate Gaseous Exchange in the Post Operative Period on the Circulation. Acta. chir. scandinav. 113: 401 (1957).

35. Thrower, W. D.; Darby, T. D.; \& Aldnger, E. E. Acid Base Derangements and Myocardial Contractility. Arch. Surg. 82: 56 (1961).

36. Arza-Mendoza, F. \& WoolF, C. R. The Value of Pulmonary Function Tests in the Assessment of Patients for Cardiac Surgery. Canad. M.A.J. 91: 1250 (1964).

37. O'Dwren, J. Fifty Cases of Croup in Private Practice, Treated by Intubation of the Larynx with a Description of the Method and of the Dangers Incident Thereto. Med. Rec. 32: 557 ( 1887 ).

38. Scroles, F. V. G. Diphtheria, Measles, Scarlatina. Melbourne: Ramsey (1927), 2nd ed., p. 121.

39. McDonald, I. H. \& Stocks, J. B. Prolonged Nasotracheal Intubation: A Review of its Development in a Pediatric Hospital. Brit. J. Anaesth. 37: 161 (1965).

40. Allen, T. H. \& Steven, I. M. Prolonged Endotracheal Intubation in Infants and Children. Brit. J. Anaesth. 37: 566 (1965).

41. Rees, J. Nasal Intubation. Paper given at The Hospital for Sick Children, Toronto, Nov. 1965.

42. Aberbeen, E. Proc. Roy. Soc. Med., Nov. (1965).

43. Davenport, H. T. Management of Respiratory Obstruction Following Removal of Tracheotomy. Canad. M. A. J. 91 : 1074 (1964).

44. Toremali, N. G. Post Operative Care and Complications after Tracheotomy in Infants and Children. Acta Anaesth. Scandinav. 4: 105 (1960).

45. Hollnnger, P. H. et al. Tracheostomy in the Newborn. Am. J. Surg. 109: 771 (June 1, 1965).

46. McClelland, R. M. A. Complications of Tracheotomy. Brit. Med. J. ii: 9567 (1965).

47. JAFFEe, S. Tracheostomy in Infancy. Laryngoscope 1336 (Octo. 1963).

48. Otrver, P. et al. Tracheotomy in Children. New England J. Med. 267: 631 (1962).

49. Harurison, G. A., \& Tonkm, J. P. Laryngeal Complications of Prolonged Endotracheal Intubation. M. J. Australia. Vol. II, I7: 709 (1965).

50. Markham, W. G. Personal communication.

51. Markham, W. \& BlackWood, M. J. A. Personal communication.

52. Nesson, N. Intrapulmonary Movement of Aerosols. Am. Rev. Resp. Dis. 83: 415 (1961).

53. Herzog, P.; Norlander, O. P.; \& Engstrom, C. G. Ultrasonic Generation of Aerosol for the Humidfication of Inspired Gas during Volume Controlled Ventilation." Acta Anaesth. Scandinav, 8: 79 (1964).

54. Unbanowicz, N.: Bond, F. O.; Pelton, D. A.; \& Conn, A. W. A New Concept of Humidification, Canad. Anaesth. Soc. J. 13: 172 (1966).

55. Musfin, W. W.; Rendell-Baker, L.; \& Thompson, P. W. Automatic Ventilation of the Lungs. Oxford: Blackwell Scientific Publications (1959).

56. Holaday, D. A. \& Ratrenberg, C. C. Automatic Lung Ventilators. Anesthesiology 23: 493 (1962).

57. Norlander, O.; Bjork, V. O.; Crafoomd, C.; Freeberg, O.; Holdmahil, M.; Swenson, A.; \& Wemman, B. Controlled Ventilation in Medical Practice. Anaesthesia 16: 285 (1961).

58. Engstrom, C. G. The Clinical Application of Prolonged Controlled Ventilation. Acta Anaesth. Scandinav. Suppl. XIII (1963).

59. Herzog, P. Personal communication.

60. Mustard, W. T. Successful Two-Stage Correction of Transposition of the Great Vessels. Surgery 55: 469 (1964).

61. Thuslen, G. A.; Mustand, W. T.; \& Fowlen, R. S. The Role of Surgery in the Treatment of Transposition of the Great Vessels. Canad. M. A. J. 91: 1096 (1964).

62. Mustard, W. T. The Diagnosis and Treatment of Complete Anomalous Pulmonary Venous Drainage. Arch. Dis. Childhood 32: 161 (1957).

63. Mustard, W. T.; Kerth, J. D.; \& Trusler, G. A. Two-Stage Correction for Total Anomalous Pulmonary Venous Drainage in Childhood. J. Thoracic \& Cardiovasc. Surg. 44: 477 ( 1962 ).

64. SLOAN, I. A. In press.

65. Spence, M. Emergency Treatment of Respiratory Failure. Anesthesiology 23: 524 (1962). 